\title{
FACTORS INFLUENCING ASCITES IN PATIENTS WITH CIRRHOSIS OF THE LIVER ${ }^{1}$
}

\author{
By ELAINE P. RALLI, JAMES S. ROBSON, DELPHINE CLARKE, AND
} CHARLES L. HOAGLAND

\author{
(From the Department of Medicine, New York University College of Medicine, and the \\ 3rd (New York University) Medical Division, Bellevue Hospital, and the \\ Hospital of the Rockeller Institute for Medical Research, \\ New York City)
}

(Received for publication August 10, 1944)

The level of serum ablumin has been said to be the controlling factor in the accumulation of ascitic fluid in patients with cirrhosis of the liver (1 to 4). Several investigators have reported an increased portal pressure in patients with the disease ( 5 to 7 ) and this has been conceded to contribute to the development of ascites. During the past 3 years, we have observed patients with cirrhosis of the liver who have accumulated ascitic fluid in such quantities that repeated paracenteses were required. The plasma levels of albumin and globulin were determined at regular intervals. The patients received, in addition to an adequate diet, an aqueous extract of liver prepared at the Rockefeller Institute for Medical Research. The liver extract, diluted with saline, was administered intravenously. As a result of the combined therapy, the reaccumulation of ascitic fluid was arrested after varying periods of time in the different patients and further paracenteses were unnecessary. We were thus able to compare the plasma levels of albumin and globulin during and after the period of fluid retention. In addition, determinations of plasma proteins were made on a group of patients with severe cirrhosis of the liver in whom ascites had never been present.

This report is concerned with these observations. As the results did not indicate that the level of albumin in the plasma was the determining factor in the fluid retention, data are presented to support another theory in explanation of this disturbance.

\section{STUDIES ON PATIENTS}

The patients selected for this study were those in whom severe liver damage was unquestionably present

\footnotetext{
1 This research was aided by grants from the Milbank
} Memorial Foundation and from the Nutrition Foundation. as evidenced by the physical findings and laboratory tests. A history of chronic alcoholism extending over a period of years was given by each patient. During the period of hospitalization, the patients were on the wards of the 3rd (New York University) Medical Division of Bellevue Hospital. When discharged, they were seen regularly in the Metabolism Clinic of New York University College of Medicine. The diet consisted of 450 grams of carbohydrate, 100 to 120 grams of protein, and 85 grams of fat. Meat was given only once a day and the rest of the protein was derived from milk, eggs, cheese, and gelatine. ${ }^{2}$ The liver extract ${ }^{8}$ was given intravenously in doses of 5 to $10 \mathrm{ml}$. diluted with $40 \mathrm{ml}$. of $\mathrm{N} / \mathrm{saline}$. Two to 3 injections were given weekly. The plasma levels of albumin and globulin were determined by the method of Howe (8). The total proteins were done by the micro Kjeldahl method. Plasma cholesterols were determined by a modification of the Schoenheimer and Sperry method (9); and were read in the photoelectric colorimeter (10). Five mgm. of bromsulphalein per $\mathrm{kgm}$. of body weight were injected intravenously for this test and the retention was determined on a sample of plasma withdrawn after one-half hour. The readings were made in a photoelectric colorimeter. The colloid osmotic pressure was calculated by the formula of Wies and Peters (11) with corrections made for the water content of the plasma using Eisenman's formula (12).

Six patients in whom severe ascites was arrested have been observed for periods of 3 months to $2 \frac{1}{2}$ years. Two patients with severe ascites died during the periods of study. One patient observed for 7 months is still accumulating ascitic fluid. Four patients had minimal or no ascites but had enlarged livers and evidences of

${ }^{2}$ Knox Gelatine, Charles B. Knox Gelatine Co., Johnstown, N. Y.

3 The liver extract used in this study was made from Lilly's 343, dried, powdered extract, by hot aqueous extraction. The extract was filtered through a Permutit tower, and the filtrate autoclaved at $\mathrm{pH} 8.3$ for $20 \mathrm{~min}$ utes at $116^{\circ} \mathrm{C}$. The $\mathrm{pH}$ was then adjusted to 7.2 and the material again filtered. The filtered extract was tested for sterility and toxicity, bottled in ampoules, and stored in a cool place until used. Full details concerning the preparation of this extract will appear in another communication. 
severe hepatic damage as shown by liver function tests and the albumin levels in the plasma.

\section{RESULTS ON PATIENTS}

In Table I are recorded the clinical data, the results of the bromsulphalein tests, and the cholesterol determinations. The levels of albumin and globulin in the plasma during the period of ascites and at varying intervals after the cessation of ascites are given in Table II, along with the calculated colloid osmotic pressure. Table III gives the albumin and globulin levels at different intervals in the patients in whom ascites was not present clinically.

In all the patients, the bromsulphalein retention was increased, and the ratio of free/total cholesterol was significantly greater than in the normal. In both groups of patients, the levels of albumin were low on admission, never exceeding 2.4 grams per cent. This was true whether or not ascites was present. The levels of globulin were elevated in all cases. In patients No. 1 to 6 (Table II), ascites was present for periods of 1 to 22 months. Cases No. 1 and 2 are remarkable in that 19 and 33 paracenteses respectively were performed and the amounts of fluid removed at each time ranged from 8 to 25 liters. As is shown in the table, ascitic fluid ceased to reaccumulate prior to any increase in the levels of albu$\mathrm{min}$ in the plasma. Plasma levels of albumin, determined at intervals of about 4 weeks, failed to show any significant change until 6 months or more after ascites was absent. In Case 1, for example, followed for a period of 22 months without ascites, no change has occurred in the level of albumin in the plasma, the latest determination in Aug. 1944 being 1.9 grams per cent. Cases 7 and 9 died while still accumulating ascitic fluid. In Case 8 , a total of 15 paracenteses have now been performed. Ascites only developed in Case 4 following episodes of severe bleeding. At such times, it was necessary to transfuse the patient and to give 5 per cent glucose infusions. The ascites was so severe as to require paracenteses on 3 occasions. The levels of albumin in the plasma were as low when no ascites was present as during the periods when it occurred.

The levels of plasma albumin in Cases 10 to 14, in whom ascites was not present on admission, were as low as in Cases 1 to 9. The patients, with the exception of case 14 , have been followed for periods of 4 to 19 months and the levels of albumin and globulin have been reported at intervals corresponding to those of the previous group. In Cases 10 and 11 who have been followed for the longest period, 14 and 19 months, the albumin levels are now 3.5 and 3.0 grams per cent.

The observations suggested that the level of albumin in the plasma was not the sole deter-

TABLE I

Data on patients

\begin{tabular}{|c|c|c|c|c|c|c|c|c|c|c|}
\hline \multirow{3}{*}{ Cases } & \multirow{3}{*}{ Age } & \multirow{3}{*}{ Sex } & \multirow{3}{*}{$\begin{array}{l}\text { Duration of } \\
\text { liver symptoms }\end{array}$} & \multirow{3}{*}{ Jaundice } & \multirow{3}{*}{ Ascites } & \multirow{3}{*}{$\begin{array}{c}\text { Spider } \\
\text { angiomata }\end{array}$} & \multicolumn{4}{|c|}{ Admission findings } \\
\hline & & & & & & & \multirow{2}{*}{$\begin{array}{l}\text { Brom- } \\
\text { sulph. } \\
\text { retention }\end{array}$} & \multicolumn{3}{|c|}{ Cholesterol } \\
\hline & & & & & & & & Total & Free & $\begin{array}{l}\text { Ratio-- } \\
\text { free/total }\end{array}$ \\
\hline $\begin{array}{r}1 \\
2 \\
3 \\
4 \\
5 \\
6 \\
7 \\
8 \\
9 \\
10 \\
11 \\
12 \\
13 \\
14\end{array}$ & $\begin{array}{c}\text { years } \\
46 \\
47 \\
66 \\
39 \\
53 \\
59 \\
57 \\
54 \\
43 \\
72 \\
40 \\
36 \\
68 \\
53\end{array}$ & $\begin{array}{l}\mathbf{M} \\
\mathbf{F} \\
\mathbf{M} \\
\mathbf{F} \\
\mathbf{M} \\
\mathbf{M} \\
\mathbf{M} \\
\mathbf{M} \\
\mathbf{M} \\
\mathbf{M} \\
\mathbf{M} \\
\mathbf{F} \\
\mathbf{F} \\
\mathbf{M}\end{array}$ & $\begin{array}{r}24 \text { months } \\
7 \text { months } \\
2 \text { weeks } \\
6 \text { months } \\
18 \text { months } \\
6 \text { weeks } \\
12 \text { months } \\
4 \text { months } \\
6 \text { weeks } \\
4 \text { years } \\
2 \text { months } \\
18 \text { months } \\
3 \text { months } \\
2 \text { months }\end{array}$ & $\begin{array}{l}\text { No } \\
\text { Slight } \\
\text { No } \\
\text { Yes } \\
\text { Yes } \\
\text { No } \\
\text { Yes } \\
\text { No } \\
\text { Yes } \\
\text { No } \\
\text { No } \\
\text { Yes } \\
\text { Slight } \\
\text { Slight }\end{array}$ & $\begin{array}{c}\text { Yes } \\
\text { Yes } \\
\text { Yes } \\
\text { At times } \\
\text { Yes } \\
\text { Yes } \\
\text { Yes } \\
\text { Yes } \\
\text { Yes } \\
\text { No } \\
\text { No } \\
\text { No } \\
\text { No } \\
\text { No }\end{array}$ & $\begin{array}{l}\text { No } \\
\text { Yes } \\
\text { No } \\
\text { Yes } \\
\text { Yes } \\
\text { No } \\
\text { Yes } \\
\text { No } \\
\text { Yes } \\
\text { No } \\
\text { No } \\
\text { Yes } \\
\text { Yes } \\
\text { Yes }\end{array}$ & $\begin{array}{c}\text { per cent } \\
21 \\
20 \\
26 \\
28 \\
20 \\
30 \\
30 \\
20 \\
35 \\
28 \\
23 \\
50 \\
23 \\
35\end{array}$ & $\begin{array}{c}\text { mgm } \\
124 \\
169 \\
127 \\
130 \\
193 \\
206 \\
113 \\
145 \\
115 \\
94 \\
200 \\
118 \\
126 \\
161\end{array}$ & $\begin{array}{l}\text { cent } \\
55 \\
57 \\
41 \\
62 \\
74 \\
78 \\
69 \\
55 \\
98 \\
31 \\
93 \\
61 \\
45 \\
83\end{array}$ & $\begin{array}{c}\text { per cent } \\
44 \\
33 \\
32 \\
48 \\
38 \\
38 \\
40 \\
38 \\
85 \\
33 \\
46 \\
52 \\
36 \\
50\end{array}$ \\
\hline
\end{tabular}


TABLE II

Data on patients with ascites

\begin{tabular}{|c|c|c|c|c|c|c|c|c|c|c|c|c|c|c|c|c|c|c|c|c|c|}
\hline \multirow{2}{*}{$\begin{array}{l}\text { Case } \\
\text { no. }\end{array}$} & \multirow{2}{*}{$\begin{array}{c}\text { Num- } \\
\text { ber } \\
\text { of } \\
\text { para- } \\
\text { centeses }\end{array}$} & \multicolumn{6}{|c|}{$\begin{array}{l}\text { Range of albumin and globulin levels } \\
\text { during period of ascites }\end{array}$} & \multirow{2}{*}{$\begin{array}{l}\text { Period } \\
\text { of no } \\
\text { ascites }\end{array}$} & \multirow{2}{*}{$\begin{array}{l}\text { No. of } \\
\text { plasma } \\
\text { determ. }\end{array}$} & \multicolumn{3}{|c|}{ After 4 weeks } & \multicolumn{3}{|c|}{ After 8 weeks } & \multicolumn{3}{|c|}{ After 6 months } & \multicolumn{3}{|c|}{ After 12 months } \\
\hline & & Alb. & Glob. & C.0.P. & Alb. & Glob. & C.o.P. & & & Alb. & Glob. & C.o.P. & Alb. & Glob. & C.0.P. & Alb. & Glob. & C.O.P. & Alb. & Glob. & C.o.P. \\
\hline \multirow[b]{2}{*}{1} & \multirow[b]{2}{*}{19} & \multicolumn{2}{|c|}{$\begin{array}{c}\text { grams } \\
\text { per cent }\end{array}$} & $\operatorname{mm}_{\mathbf{H}} \mathrm{O}$ & \multicolumn{2}{|c|}{$\underset{\text { per cent }}{\text { grams }}$} & $\operatorname{mm}_{\mathrm{H}_{2} \mathrm{O}}$ & \multirow{2}{*}{\begin{tabular}{|c|} 
months \\
20
\end{tabular}} & \multirow[b]{2}{*}{20} & \multicolumn{2}{|c|}{$\underset{\text { per cent }}{\text { grams }}$} & $\min _{\mathrm{H}_{2} \mathrm{O}}$ & \multicolumn{2}{|c|}{$\underset{\text { per cent }}{\text { grams }}$} & $\operatorname{mim}_{H_{2} \mathrm{O}}$ & \multicolumn{2}{|c|}{$\begin{array}{c}\text { grams } \\
\text { per cent }\end{array}$} & $\operatorname{mim}_{\mathrm{H}_{2} \mathrm{O}}$ & \multicolumn{2}{|c|}{$\begin{array}{c}\text { grams } \\
\text { per cent }\end{array}$} & $\operatorname{mm}_{\mathrm{H}_{2} \mathrm{O}}$ \\
\hline & & 1.7 & 4.9 & 179 & 1.9 & 3.9 & 166 & & & 1.4 & 5.4 & 174 & 1.8 & 5.2 & 194 & 2.0 & 4.2 & 188 & 1.9 & 4.4 & 179 \\
\hline 3 & 3 & 1.7 & 3.9 & 171 & 1.4 & 4.0 & 148 & 20 & 14 & 1.7 & 4.0 & 166 & 2.6 & 4.2 & 224 & 3.0 & 3.7 & 237 & 3.4 & 3.2 & 247 \\
\hline 4 & 3 & 2.4 & 5.6 & 246 & 1.8 & 4.9 & 185 & $*$ & 14 & 2.3 & 5.3 & 228 & 2.6 & 5.2 & 244 & & & & & & \\
\hline 5 & 1 & 1.6 & 4.6 & 168 & 1.8 & 3.9 & 160 & 4 & 4 & 2.0 & 4.3 & 183 & 1.9 & 4.0 & 167 & 2.1 & 3.9 & 178 & & & \\
\hline 6 & 1 & 1.8 & 3.6 & 153 & & & & 2 & 2 & 2.7 & 3.9 & 221 & 2.4 & 4.7 & 223 & & & & & & \\
\hline 7 & 5 & 1.7 & 3.8 & 151 & 1.8 & 3.8 & 157 & & ed while & still acc & umulat & ting & & & & & & & & & \\
\hline 9 & 0 & 1.6 & 3.7 & 143 & 1.6 & 3.6 & 141 & & ed while & still sec & umulat & & & & & & & & & & \\
\hline
\end{tabular}

* Occurred at intervals accompanying bleeding episodes.

mining factor in the production of ascites. In considering other factors that might induce fluid retention, it seemed possible that the low urine volume (13) present in patients with cirrhosis of the liver might be the cause rather than the result of water retention. In 1940, the presence of an antidiuretic factor in the urine of patients with nephrosis and premenstrual edema was reported (14). On the premise that a similar substance might be present in the urine of patients with cirrhosis and ascites, the antidiuretic effect of aliquots of dialyzed urine from the patients was studied.

\section{PROCEDURE}

Urine was collected from 4 normal individuals and from 8 of the patients with cirrhosis of the liver. All subjects received an adequate fluid intake during the period of urine assay.

Preparation of urine. The urine was extracted, with slight modification, by the method reported by several workers $(14,15,16,27,28)$. Twenty-fout-hour specimens were collected under toluene and acidified with 3 per cent acetic acid. Evaporation at room temperature to volumes of about $80 \mathrm{ml}$. was accomplished by suspension of the urine in cellophane sacks ${ }^{4}(1 \%$ inches $\times 2$ to 3 feet) before electric fans. This reduction in volume was completed in from 36 to 48 hours. Electrolytes were removed by dialysis in a stream of running water, the process being facilitated by constant oscillation through an angle of $30^{\circ}$. The urine became chloridefree in 6 to 8 hours. The final volume was brought to $100 \mathrm{ml}$. One $\mathrm{ml}$. of this solution was used for each

4 Visking Cellulose Sausage Casings- $36 / 32$ "NoJax" Casing.

TABLE III

Data on patients with no clinical ascites

\begin{tabular}{|c|c|c|c|c|c|c|c|c|c|c|c|c|c|c|}
\hline \multirow{2}{*}{$\begin{array}{l}\text { Case } \\
\text { no. }\end{array}$} & \multirow{2}{*}{$\begin{array}{c}\text { Total } \\
\text { time } \\
\text { observed }\end{array}$} & \multicolumn{3}{|c|}{ Control period } & \multicolumn{3}{|c|}{ After 8 weeks } & \multicolumn{3}{|c|}{ After 6 months } & \multicolumn{3}{|c|}{ After 12 months } & \multirow{2}{*}{$\begin{array}{c}\text { Total } \\
\text { no. of } \\
\text { plasma } \\
\text { determ. }\end{array}$} \\
\hline & & Alb. & Glob. & C.O.P. & Alb. & Glob. & \multirow{2}{*}{ 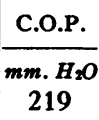 } & Alb. & Glob. & C.O.P. & Alb. & Glob. & \multirow{2}{*}{$\frac{\text { C.O.P. }}{\frac{m m . \mathrm{H}_{2} \mathrm{O}}{232}}$} & \\
\hline 10 & $\begin{array}{c}\text { months } \\
17\end{array}$ & \multicolumn{2}{|c|}{ grams per cent } & $\begin{array}{c}m m . \mathrm{H}_{2} \mathrm{O} \\
205\end{array}$ & $\begin{array}{l}\text { grams } \\
2.6\end{array}$ & grams per cent & & \multicolumn{2}{|c|}{ grams per cent } & $\begin{array}{c}\mathrm{mm} . \mathrm{H}_{2} \mathrm{O} \\
219\end{array}$ & \multicolumn{2}{|c|}{ grams per cent } & & 14 \\
\hline 11 & 12 & 2.4 & 4.1 & 209 & 2.3 & 3.3 & 250 & 2.9 & 3.5 & 226 & $3.5^{(}$ & $\begin{array}{c}\text { mont } \\
2.7\end{array}$ & 252 & 10 \\
\hline 12 & 5 & 1.7 & 4.5 & 190 & 2.2 & 4.6 & 208 & 2.2 & $\begin{array}{c}\text { montt } \\
4.3\end{array}$ & 201 & & & & 5 \\
\hline 13 & 8 & 2.3 & 4.3 & 208 & 2.7 & 3.9 & 221 & 2.4 & 3.7 & 202 & & & & 9 \\
\hline 14 & 2 & 2.2 & 4.3 & 201 & & & & & & & & & & \\
\hline
\end{tabular}


assay, an amount which represented just under $15 \mathrm{~min}$ utes urine output.

Method of Assay. Assay of the antidiuretic activity was performed by the method of Burn (17). The rats used were adult males from the laboratory stock weighing 120 to 240 grams. They had been maintained on a standard Nu Chow diet and water had been given ad lib. Food was removed 12 to 18 hours before the assay was performed. Water was allowed up to the time of assay. Series of 4 rats were placed in metabolism cages. Two series were used for each assay and the difference in total rat weight in each series was not greater than 10 per cent. The animals were hydrated to 5 per cent of their body weight with lukewarm tap water, given by means of a gastric tube. Immediately after hydration an intraperitoneal injection of $1 \mathrm{ml}$. of the solution to be assayed was given to each rat. The urine was collected and the volumes recorded, after the first 30 to 45 minutes, at 15-minute intervals. Fecal contamination was prevented by use of a fine wire mesh and a small amount of glass wool in the neck of the funnel. In a certain number of experiments, determinations of the total chloride excretion in each cage for a 2-hour period were made by the open Carius method of the Volhard titration as applied by Van Slyke (18). Pitressin (Parke Davis), as commercially prepared, was assayed for its antidiuretic activity and for its ability to stimulate the excretion of chlorides. The effect of pitressin added to the urine of normal individuals and dialyzed for 6 to 8 hours was studied in a similar manner.

A total of 200 rats was used in the determinations. Six types of experiment were performed: (1) Assay of known amounts of pitressin (Parke Davis) for antidiuretic activity. (2) Assay of known amounts of pitressin subjected to dialysis for antidiuretic activity. (3) Assay of urine from normal individuals for antidiuretic activity. (4) Assay of urine from patients with cirrhosis of the liver for antidiuretic activity. (5) Establishment of diuretic curves for the rat group when hydrated and given $1 \mathrm{ml}$. of distilled water intraperitoneally. (6) The total chloride excretion was determined in the urines of the rats in experiments $1,2,4$, and 5 .

\section{RESULTS}

In each assay, the diuretic response of 4 hydrated rats was recorded in the form of a graph, plotting the time taken for excretion against the volumes of urine excreted. This latter was expressed as the percentage of the total amount of the water administered. To facilitate comparison, results are expressed as the time in minutes required for the excretion of 25 per cent and 50 per cent of the volume of water administered in the hydration. Each assay was done in duplicate.

Control experiments on diuresis. As good correlation between dose and response has been shown to occur following the injection of known

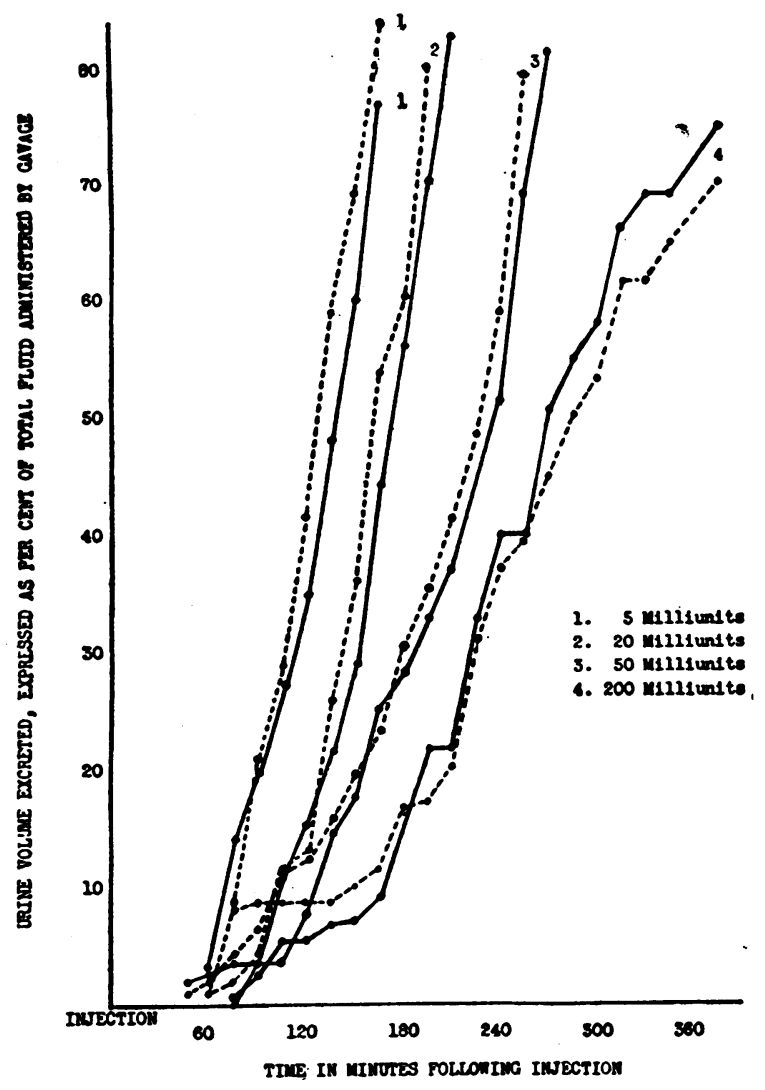

Fig. 1. The Antidiuretic Effect in Hydrated Rats of Graded Doses of Pitressin (Parke Davis) Given INTRAPERITONEALLY

amounts of pitressin $(16,28)$, only a few experiments of this type were performed. In Figure 1 are plotted the results obtained with $5,20,50$, and 200 milliunits of pitressin given intraperitoneally. The averages of the times required for 25 per cent excretion following injections of the above doses were, respectively, $98,135,170$, and 210 minutes. The corresponding averages required for 50 per cent excretion were 135, 173, 233 , and 278 minutes. The biological response to the doses of pitressin used was greatest between the ranges of 5 to 50 milliunits.

Seven experiments were performed in which known amounts of pitressin were added to about $100 \mathrm{ml}$. of normal urine and the mixture dialyzed from 7 to 8 hours. The antidiuretic potency of the solution was then assayed. One ml. of this preparation, which had originally contained 20 milliunits of pitressin, was injected intraperitoneally. Six experiments were done in which the 
antidiuretic potency of 20 milliunits of pitressin was assayed without previous dialysis. The antidiuretic activity of the two solutions was then compared and in all 13 assays the antidiuretic effects of both dialyzed and undialyzed pitressin were found to be of equal magnitude. The results of typical experiments are shown in Figure 2.

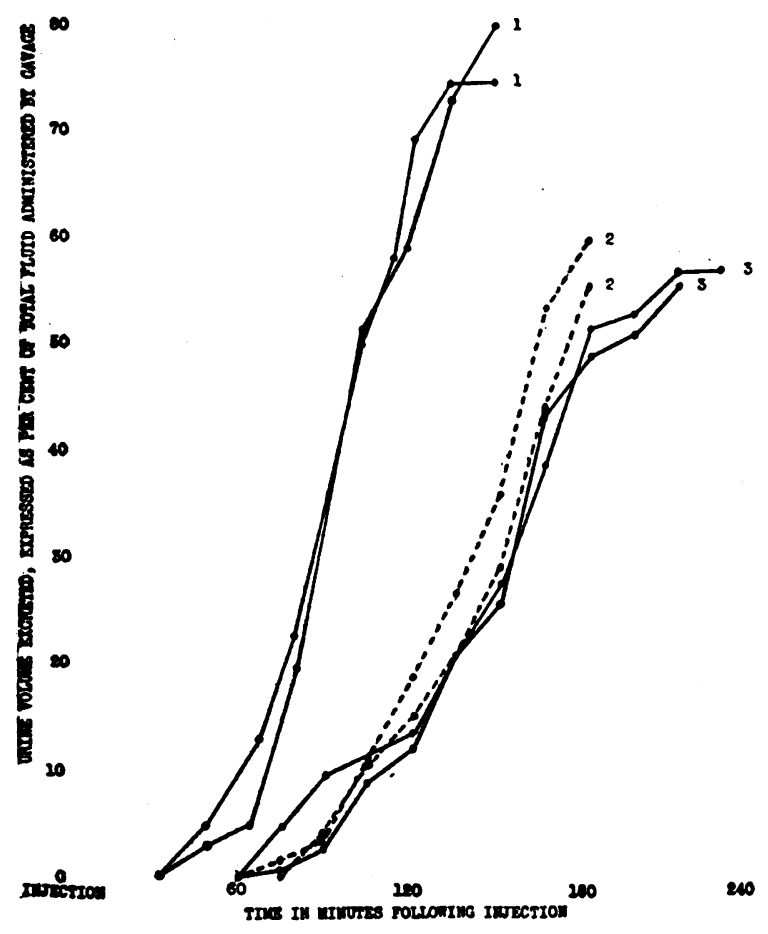

Fic̄. 2. Effect of Dialysis Upon Antidiuretic Actrvity of Pitressin (Parke Davis)

1. Hydrated rats given $1 \mathrm{ml}$. distilled water intraperitoneally. 2. Hydrated rats given 20 milliunits pitressin (undialyzed) intraperitoneally. 3. Twenty milliunits of pitressin dialyzed in urine for 7 hours given intraperitoneally to hydrated rats.

There was almost complete superimposition of the excretory curves in the two types of assay. In the experiments in which pitressin was previously dialyzed, the averages of the number of minutes required for 25 per cent and 50 per cent excretion were 135 and 173 minutes, respectively. The corresponding averages for undialyzed pitressin were 135 and 172 minutes.

In order to establish the excretory curve following hydration to 5 per cent of body weight, 12 experiments were performed on groups of 4 rats. One ml. of distilled water was given intra-
TABLE IV

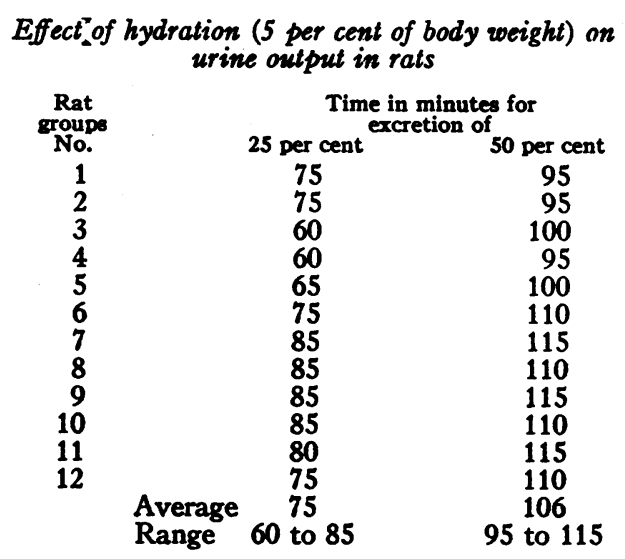

peritoneally to each animal after hydration to simulate the conditions of the experiments with urine. The results are shown in Table IV. The time required for 25 per cent excretion ranges from 60 to 85 minutes, and for 50 per cent excretion from 95 to 115 minutes, with averages of 75 minutes and 106 minutes, respectively.

Results of assay of human urines. Twentyfour-hour specimens of urine from 4 normal individuals were assayed for their antidiuretic activity. In 1 case, the assay was performed on 2 separate urine samples. The results of the experiments are shown in Table $\mathrm{V}$ and indicate that normal urine has a slight antidiuretic activity. The time taken for 25 per cent excretion averaged $97 \mathrm{~min}$ utes, and for 50 per cent excretion, the average was 115 minutes. The ranges of the two were 75 to 115 and 125 to 185 minutes, respectively. Assay of antidiuretic activity was performed on 24-hour urine samples from 8 cases with cirrhosis of the liver. In 1 case, two 24-hour samples were assayed. Cases 7, 8, and 9 (Table V) were patients who had massive ascites and considerable peripheral edema at the time the urine was assayed. Cases 1, 2, and 4 were patients in whom massive ascites and edema had been present for a considerable time but in whom there was no ascites demonstrable at the time of the assay. In these cases, ascitic fluid had not accumulated for periods of 3 to 16 months prior to the assay. Cases 10 and 14 were patients with severe hepatic cirrhosis in whom ascites and edema had never been present to any demonstrable extent. In Cases 7, 8, and 9, the time required for 25 per cent excretion ranged from 175 to 215 minutes. 
TABLE V

Effects on urine output in hydrated rats of the intraperitoneal injection of the extract of urines of normal and cirrhotic subjects

\begin{tabular}{|c|c|c|c|c|c|c|c|c|c|c|c|c|c|c|}
\hline & \multicolumn{8}{|c|}{ Cases with cirrhosis of the liver } & \multicolumn{6}{|c|}{ Normal subjects } \\
\hline & \multirow{2}{*}{$\begin{array}{l}\text { Case } \\
\text { no. }\end{array}$} & \multirow{2}{*}{ Sex } & \multirow{2}{*}{ Sp. gr. } & \multirow{2}{*}{$\begin{array}{c}\text { 24-hour } \\
\text { urine } \\
\text { vol. }\end{array}$} & \multirow{2}{*}{$\mid \begin{array}{c}\text { Degree } \\
\text { of } \\
\text { ascites }\end{array}$} & \multirow{2}{*}{$\begin{array}{l}\text { Periph. } \\
\text { edema }\end{array}$} & \multicolumn{2}{|c|}{$\begin{array}{l}\text { Time for } \\
\text { excretion of }\end{array}$} & \multirow{2}{*}{$\begin{array}{l}\text { Case } \\
\text { no. }\end{array}$} & \multirow{2}{*}{ Sex } & \multirow{2}{*}{ Sp. gr. } & \multirow{2}{*}{$\begin{array}{c}\text { 24-hour } \\
\text { urine } \\
\text { vol. }\end{array}$} & \multicolumn{2}{|c|}{ Time for excretion of } \\
\hline & & & & & & & $\begin{array}{l}25 \text { per } \\
\text { cent }\end{array}$ & $\begin{array}{l}50 \text { per } \\
\text { cent }\end{array}$ & & & & & 25 per cent & 50 per cent \\
\hline \multirow{5}{*}{ 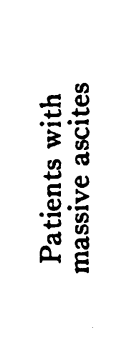 } & & & & $m l$. & & & \multicolumn{2}{|c|}{ minutes } & & \multirow[b]{2}{*}{$\mathbf{M}$} & \multirow[b]{2}{*}{1.010} & \multirow{2}{*}{$\begin{array}{c}m l . \\
1350\end{array}$} & \multicolumn{2}{|c|}{ minutes } \\
\hline & 8-A & $\mathbf{M}$ & 1.020 & 1000 & $4+$ & $2+$ & $\begin{array}{l}195 \\
215\end{array}$ & $\begin{array}{l}360 \\
370\end{array}$ & $\mathbf{R}$ & & & & $\begin{array}{r}95 \\
110\end{array}$ & $\begin{array}{l}130 \\
135\end{array}$ \\
\hline & 8-B & $\mathbf{M}$ & 1.020 & 585 & $4+$ & $2+$ & $\begin{array}{l}190 \\
175\end{array}$ & $\begin{array}{l}320 \\
305\end{array}$ & D & $\mathbf{F}$ & 1.010 & 1600 & 75 & 150 \\
\hline & 9 & $\mathbf{M}$ & 1.020 & 800 & $3+$ & $2+$ & $\begin{array}{l}195 \\
190\end{array}$ & $\begin{array}{l}300 \\
330\end{array}$ & $\mathbf{S}$ & $\mathbf{M}$ & 1.025 & 1100 & $\begin{array}{l}90 \\
95\end{array}$ & $\begin{array}{l}180 \\
185\end{array}$ \\
\hline & 7 & $\mathbf{M}$ & 1.030 & 410 & $3+$ & $2+$ & $\begin{array}{l}180 \\
175\end{array}$ & $\begin{array}{l}225 \\
245\end{array}$ & G-1 & $\mathbf{M}$ & 1.015 & 1080 & $\begin{array}{r}85 \\
105\end{array}$ & $\begin{array}{l}120 \\
135\end{array}$ \\
\hline \multirow{3}{*}{ 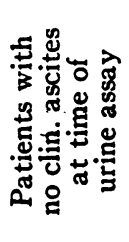 } & 2 & $\mathbf{F}$ & 1.015 & 1600 & $\mathbf{0}$ & 0 & $\begin{array}{l}150 \\
145\end{array}$ & $\begin{array}{l}200 \\
205\end{array}$ & G-2 & $\mathbf{M}$ & 1.014 & 1200 & $\begin{array}{l}100 \\
115\end{array}$ & $\begin{array}{l}125 \\
145\end{array}$ \\
\hline & 4 & $\mathbf{F}$ & 1.015 & 1420 & $\mathbf{0}$ & $\mathbf{0}$ & $\begin{array}{l}150 \\
155\end{array}$ & $\begin{array}{l}215 \\
205\end{array}$ & \multicolumn{5}{|c|}{$\begin{array}{l}\text { Average } \\
\text { Range }\end{array} \quad 97$ to 115} & $\begin{array}{c}145 \\
120 \text { to } 185\end{array}$ \\
\hline & 1 & $\mathbf{M}$ & 1.010 & 1650 & $\mathbf{0}$ & 0 & $\begin{array}{l}130 \\
150\end{array}$ & $\begin{array}{l}160 \\
190\end{array}$ & & & & & & \\
\hline \multirow{2}{*}{ 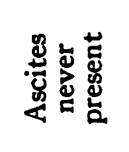 } & 14 & $\mathbf{M}$ & 1.014 & 1500 & $\mathbf{0}$ & 0 & $\begin{array}{l}125 \\
110\end{array}$ & $\begin{array}{l}160 \\
165\end{array}$ & & & & & & \\
\hline & 10 & $\mathbf{M}$ & 1.014 & 1320 & $\mathbf{0}$ & $\mathbf{0}$ & $\begin{array}{l}75 \\
85\end{array}$ & $\begin{array}{l}105 \\
120\end{array}$ & & & & & & \\
\hline
\end{tabular}

In Cases 1, 2, and 4, excretion of 25 per cent of administered water occurred from 130 to 155 minutes, while in Cases 10 and 14, the time required was 75 to 125 minutes. The corresponding values for 50 per cent excretion were 225 to 370 minutes, 160 to 215 minutes, and 105 to 165 minutes, respectively.

It is clear that the urine of patients with cirrhosis of the liver and ascites had a greater antidiuretic effect when injected into hydrated rats than did the urine from patients without ascites. Moreover, the magnitude of the effect seemed to parallel the degree of ascites. As can be seen from the results in Table $\mathrm{V}$, the antidiuretic activity of the urine of patients 10 and 14, in whom ascites had never been present clinically, fell within the range of the antidiuretic activity of the urine of normal persons.

Observations on chloride excretion. In order to examine the effects upon chloride excretion of the extract of urine from patients with cirrho- sis of the liver, the total chloride excretion was determined in groups of 4 rats hydrated to 5 per cent of their body weight. The results are shown in Table VI. The total chloride is expressed in micro-equivalents per 100 grams of rat weight, excreted in the 2-hour period following the intraperitoneal injection. The total chloride excretion in Figure 3 is expressed in micro-equivalents per 100 grams of rat weight for a 2 -hour period and is plotted against the antidiuretic effect obtained with the substance injected. The urine output in the 2-hour period was measured and that volume, expressed as a percentage of the total amount of water administered by gavage, is used to indicate the antidiuretic response.

Five experiments were performed in which 1 $\mathrm{ml}$. of distilled water was injected intraperitoneally into hydrated rats. The total chloride excretion per 100 grams of rat weight in the ensuing 2-hour period ranged from 23.8 to 35.0 microequivalents, with an average of 27.3 micro- 
equivalents. In 6 experiments in which hydrated rats were given 20 milliunits of pitressin (Parke Davis) in a volume of $1 \mathrm{ml}$. of water, the chloride excretion per 100 grams of rat weight in the same period ranged from 51.3 to 67.6 microequivalents, the average being 60.2 microequivalents. Commercial pitressin was added to the urine of a normal individual and dialyzed for 6 to 8 hours. Six experiments were performed in which $1 \mathrm{ml}$. of this solution, which had originally contained 20 milliunits of pitressin, was assayed for its antidiuretic activity and its ability to stimulate the excretion of chlorides. As previously mentioned, there was no loss in antidiuretic potency. When injected intraperitoneally into hydrated rats, the total chloride excretion per 100 grams of rat weight per 2-hour period ranged from 20.1 to 34.4 micro-equivalents. The average chloride excretion in these experiments was 27.6 micro-equivalents. Six experiments were performed in which $1 \mathrm{ml}$. of a urine extract from a patient with cirrhosis of the liver was given intraperitoneally to hydrated rats. The chloride excretion per 100 grams of rat weight per 2-hour

TABLE VI

Observations on chloride excretion

Total chloride excreted per 100 grams rat weight in 2-hour period after hydration to 5 per cent of body weight, and injected as indicated.

Chlorides are expressed in micro-equivalents

\begin{tabular}{|c|c|c|c|c|}
\hline $\begin{array}{c}\text { Exp. } \\
\text { no. }\end{array}$ & $\begin{array}{c}1 \mathrm{ml} \\
\text { distilled } \\
\text { water } \\
\text { injected } \\
\text { intra- } \\
\text { peritoneally }\end{array}$ & $\begin{array}{c}20 \text { milliunits } \\
\text { of pitressin } \\
\text { (Parke- } \\
\text { Davis) } \\
\text { injected } \\
\text { intra- } \\
\text { peritoneally }\end{array}$ & $\begin{array}{c}20 \text { milliunits } \\
\text { of pitressin- } \\
\text { dialyzed } \\
\text { injected } \\
\text { intra- } \\
\text { peritoneally }\end{array}$ & $\begin{array}{c}1 \mathrm{ml} \text {. urine } \\
\text { extract from } \\
\text { patients with } \\
\text { cirrhosis of } \\
\text { liver and } \\
\text { ascites, } \\
\text { injected } \\
\text { intra- } \\
\text { peritoneally }\end{array}$ \\
\hline 1 & $\begin{array}{l}27.0 \\
27.4\end{array}$ & $\begin{array}{l}67.6 \\
67.2\end{array}$ & $\begin{array}{l}34.1 \\
34.4\end{array}$ & $\begin{array}{l}23.5 \\
23.1\end{array}$ \\
\hline 2 & $\begin{array}{l}25.6 \\
26.7\end{array}$ & $\begin{array}{l}51.8 \\
51.3\end{array}$ & $\begin{array}{l}29.6 \\
30.1\end{array}$ & $\begin{array}{l}21.9 \\
21.2\end{array}$ \\
\hline 3 & $\begin{array}{l}23.8 \\
24.3\end{array}$ & $\begin{array}{l}63.1 \\
63.5\end{array}$ & $\begin{array}{l}22.5 \\
22.0\end{array}$ & $\begin{array}{l}19.0 \\
19.0\end{array}$ \\
\hline 4 & $\begin{array}{l}34.5 \\
35.0\end{array}$ & $\begin{array}{l}65.7 \\
65.1\end{array}$ & $\begin{array}{l}20.1 \\
20.6\end{array}$ & $\begin{array}{l}21.9 \\
21.2\end{array}$ \\
\hline 5 & $\begin{array}{l}23.9 \\
25.1\end{array}$ & $\begin{array}{l}54.5 \\
53.5\end{array}$ & $\begin{array}{l}24.4 \\
24.7\end{array}$ & $\begin{array}{l}12.6 \\
13.0\end{array}$ \\
\hline 6 & & $\begin{array}{l}60.3 \\
59.1\end{array}$ & $\begin{array}{l}34.2 \\
34.3\end{array}$ & $\begin{array}{l}15.4 \\
15.8\end{array}$ \\
\hline $\begin{array}{l}\text { Range } \\
\text { Average }\end{array}$ & $\begin{array}{c}23.8 \text { to } 35.0 \\
27.3\end{array}$ & $\left|\begin{array}{c}51.3 \text { to } 67.6 \\
60.2\end{array}\right|$ & $\left|\begin{array}{c}20.1 \text { to } 34.4 \\
27.6\end{array}\right|$ & $\begin{array}{c}12.6 \text { to } 23.5 \\
19.2\end{array}$ \\
\hline
\end{tabular}

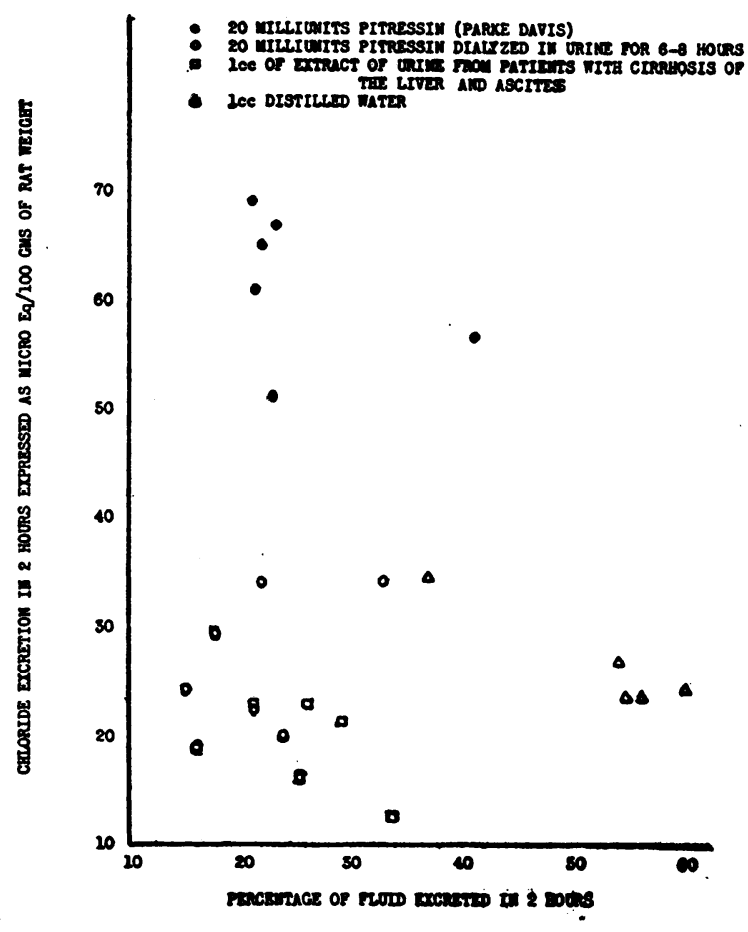

Fig. 3. Water and Chloride Excretion in $\mathbf{H y -}$ DRATEd Rats Following THE INTRAPERITONEal INJECtion of Commercial Pitressin, Dialyzed Pitressin, the Extract of Urine from Patients with CirrhoSis, and Distilled Water

period ranged from 12.6 to 23.5 with an average excretion of 19.2 micro-equivalents. The results indicate that the antidiuretic factor present in the urine of patients with cirrhosis of the liver does not possess the ability to stimulate the excretion of chlorides. They confirm the chloruretic activity of undialyzed pitressin (19 to 22 ) and show that this property is lost by dialysis.

\section{DISCUSSION}

Our observations on the plasma levels of albumin in patients with cirrhosis of the liver, both with and without ascites, suggest that ascites in such patients is not determined solely by the level of albumin in the plasma or by the oncotic pressure thereby exerted. Moreover, it would seem that far too much emphasis has been placed on the critical level of albumin in the plasma as a determining factor in the production of ascites. Not only do the data that we have presented fail to support this contention but there are several reports in the literature which agree with this 
idea. In 1939, Butt, Snell and Keys (23) reported the oncotic pressure in patients with cirrhosis of the liver and in patients with obstructive jaundice. Only 2 of their patients with obstructive jaundice had ascites, while ascites was present in all of the patients with cirrhosis. The oncotic pressures, however, were as low in the patients with obstructive jaundice as in the patients with cirrhosis and ascites.

In the patients we have observed in whom ascites was controlled, the plasma levels of albumin have remained well below the normal value for at least 6 months. Until more cases have been studied one cannot know whether or not the plasma levels of albumin will ever return to and remain at the accepted lower level of normal, 3.8 grams per cent (24). It is equally significant that in the patients in whom ascites was never present, the plasma levels of albumin were all below the normal level.

The observation that there is a decrease in urine output in patients with cirrhosis of the liver is not new. In 1901, Gilbert and Lerebouillet (13) reported that the output of urine was decreased in such patients. Pick (25), in 1929, stated that in certain cases of nephrosis there was an increased diuresis following liver extract therapy. He discussed the question of a "liver hormone" in relation to water metabolism and cited the experimental work of Glaubach and Molitor on the effect of an injection of liver extract on water diuresis in a dog with kidney damage. Ratnoff and Patek (26) also mention the water retention in cirrhosis of the liver but consider that the "lowering of serum albumin and therefore of oncotic pressure is ample explanation for water retention in most cases of cirrhosis of the liver." They agree, however, that there may be other factors involved.

The nature of the antidiuretic effect which we have observed with urines from patients with cirrhosis of the liver cannot be defined at this time. That the effect may be due to a substance of pituitary origin should be considered. The method that was used for its extraction from the urine was that described $(15,27,28)$ for the extraction of the antidiuretic hormone of the pituitary. All of these investigators found that with this method, the substance could not be extracted from the urine of animals unless the posterior pituitary or the hypothalamic-hypophyseal system was intact. Furthermore, with this method an antidiuretic substance was recovered (14) from the urine following the injection of pitressin into normal individuals, and the recovered substance exerted an antidiuretic effect equal to that of the amount of pitressin injected. It has been argued (29) that the substance extracted from urine is not pituitary in origin because it does not cause, when injected, an increased excretion of chlorides. This statement is contradicted by our experiments which show that the chloruretic activity of commercially prepared pitressin is lost by dialysis although the antidiuretic potency remains unchanged. If the substance is pituitary in origin, it may be that the reason for finding it in increased concentrations in the urine of patients with cirrhosis of the liver and ascites is due to the fact that the damaged liver has lost the capacity to inactivate this hormone. There is evidence that the liver does inactivate some of the hormones and it has been reported that a suspension of liver may inactivate the antidiuretic hormone of the pituitary (30).

Another factor which may enter into the increase in concentration" of the antidiuretic substance in the patients with ascites and cirrhosis is dehydration. Ham and Landis (29) reported that, in 1 female subject "dehydrated to a moderate degree," there was a moderate amount of antidiuretic substance excreted in the urine. In one of our normal male subjects, fluids were restricted so that the total urine output for 24 hours was $930 \mathrm{ml}$. and the specific gravity was 1.032 . The antidiuretic effect of this urine was in the upper limits of normal; e.g., the time in minutes required for the excretion of 25 per cent of the ingested water in the rats averaged 123 minutes whereas the upper limit of normal in the other 4 subjects was 115 minutes. Fifty per cent of the ingested water was excreted in 180 minutes by the rats receiving the antidiuretic extract from this patient's urine.

Although it is indubitably true that the plasma levels of albumin are low in patients with cirrhosis of the liver, the evidence that this is the determining factor in fluid retention is open to question. The very fact that the albumin level is low, whether or not ascites is present in patients, would in itself contradict the hypothesis. Our 
observations have shown that there is some correlation between the degree of ascites in patients with cirrhosis and the antidiuretic activity of the urine. Granted, that there is a certain amount of dehydration present in the patients with ascites, the possibility still exists that fluid retention in such patients may be influenced by some antidiuretic factor which is effective in suppressing urine output. The exact nature of this substance is not known but it is possible that it may have its origin in the posterior pituitary. The fact that the antidiuretic effect is not equally present in all patients with cirrhosis of the liver, but is marked in the patients with ascites, suggests that, in spite of severe liver damage, all functions of the liver are not equally impaired. In the patients in whom ascites has not occurred, it is probable that the capacity of the liver to detoxify certain substances is still intact. The cessation of the accumulation of ascitic fluid in 6 of the patients treated with the high carbohydrate, high protein diet and with liver extract, confirms the observations of Patek and Post (31) that this combined form of therapy is indicated in the treatment of patients with cirrhosis of the liver. These investigators administered liver extract, $5 \mathrm{ml}$. intramuscularly, twice weekly along with a high protein diet.

\section{SUM MARY}

Observations are reported on the plasma levels of albumin and globulin in patients with cirrhosis of the liver, with and without ascites. The plasma levels of albumin were low in both groups. Following treatment with diet and intravenous liver extract, reaccumulation of ascitic fluid ceased in 6 patients and this occurred before there was any increase in the levels of albumin in the plasma. Determinations of the plasma at monthly intervals in the patients showed no significant increase in the level of albumin for as long as 6 months after the ascites was absent.

The urine of the patients with and without ascites and of normal subjects was assayed for its antidiuretic activity. It was found that the urine of patients with ascites when injected into hydrated rats delayed the excretion of urine. The urine from patients in whom ascites was never present possessed an antidiuretic effect similar to that obtained with the urine from normal subjects.
The urine of patients in whom ascites had been controlled prior to assay had an antidiuretic effect greater than the urine of normal subjects but less than that obtained with urine from patients with ascites. The nature of the antidiuretic substance obtained from the urine has not been ascertained. Based on the methods of extraction and on the work of other investigators, it is suggested that the antidiuretic substance may have its origin in the posterior pituitary.

Pitressin as commercially prepared was found to exert its full antidiuretic activity after dialysis. This procedure, however, resulted in a loss of the chloruretic effect of the hormone.

\section{BIBLIOGRAPHY}

1. Post, J., and Patek, A. J., Jr., Serum proteins in relation to liver disorders. Bull. New York Acad. Med., 1943, 19, 815.

2. Myers, W. K., and Keefer, C. S., The relation of plasma proteins to ascites and edema in cirrhosis of the liver. Arch. Int. Med., 1935, 55, 349.

3. Post, J., and Patek, A. J., Jr., Serum proteins in cirrhosis of the liver; relation to prognosis and formation of ascites. Arch. Int. Med., 1942, 69, 67.

4. Tumen, H., and Bockus, H. L., Clinical significance of serum proteins in hepatic diseases compared with other liver function tests. Am. J. M. Sc., 1937, 193, 788.

5. Bellis, C. J., Portal venous pressure in man. Proc. Soc. Exper. Biol. and Med., 1942, 50, 258.

6. Thompson, W. P., Caughey, J. L., Whipple, A. O., and Rousselot, L. M., Splenic vein pressure in congestive splenomegaly. J. Clin. Invest., 1937, 16, 571.

7. McIndoe, A. H., Vascular lesions of portal cirrhosis. Arch. Path. and Lab. Med., 1928, 5, 23.

8. Howe, P. E., The determination of proteins in the blood-A micromethod. J. Biol. Chem., 1921, 49, 109.

9. Schoenheimer, R., and Sperry, W. M., A micromethod for the determination of combined and free cholesterol. J. Biol. Chem., 1934, 106, 745.

10. Clarke, D., and A. F. Marney, J. Lab. and Clin. Med., In press.

11. Wies, C. H., and Peters, J. P., The osmotic pressure of proteins in whole serum. J. Clin. Invest., 1937, 16, 93.

12. Eisenman, A. J., MacKenzie, L. B., and Peters, J. P., Protein and water of serum and cells of human blood. J. Biol. Chem., 1936, 116, 33.

13. Gilbert, A., and Lereboiullet, $P$., Des urines retardees (opsiurie) dans les cirrhoses. Compt. rend. Soc. de biol., 1901, 11 Serie 3. 276. 
14. Robinson, F. H., Jr., and Farr, L. E., The relation between clinical edema and the excretion of an antidiuretic substance in the urine. Ann. Int. Med., 1940, 14, 42.

15. Gilman, A., and Goodman, L., The secretory response of the posterior pituitary to the need for water conservation. J. Physiol., 1937, 90, 113.

16. Teel, H. M., and Reid, D. E., Observations upon the ocurrence of an antidiuretic substance in the urine of patients with pre-eclampsia and eclampsia. Endocrinology, 1939, 24, 297.

17. Burn, J. H., Estimation of the antidiuretic potency of pituitary (post. lobe) extracts. Quart. J. Pharm. and Pharmacol., 1931, 4, 517.

18. Van Slyke, D. D., The determination of chlorides in blood and tissues. J. Biol. Chem., 1923, 58, 523.

19. Smith, F. M., and MacKay, E. M., Influence of posterior pituitary extracts on sodium balance. Proc. Soc. Exper. Biol. and Med., 1936, 34, 116.

20. Manchester, R. C., Influence of posterior pituitary extracts on mineral and water exchange. Proc. Soc. Exper. Biol. and Med., 1932, 29, 717.

21. Ham, G. C., Reproducible diuresis and chloruresis for bioassay of antidiuretic activity. Proc. Soc. Exper. Biol. and Med., 1943, 53, 210.

22. Silvette, $H$., The influence of posterior pituitary extract on the excretion of water and chlorides by the renal tubules. Am. J. Physiol., 1940, 128, 747.

23. Butt, H. R., Snell, A. M., and Keys, A., Plasma protein in hepatic disease; a study of the colloid os- motic pressure of blood serum and of ascitic fluid in various diseases of the liver. Arch. Int. Med., 1939, 63, 143.

24. Peters, J. P., and Van Slyke, D. D., Quantitative Clinical Chemistry. Interpretations. Williams and Wilkins, Baltimore, 1931. P. 662.

25. Pick, E. P., The regulation of water metabolism. Harvey Lectures, New York, 1929-30. Series XXV, p. 32.

26. Ratnoff, O. D., and Patek, A. J., Jr., The natural 'history of Laennec's cirrhosis of the liver. An analysis of 386 cases. Medicine, 1942, 21, 207.

27. Ingram, W. R., Ladd, L., and Benbow, J. T., The excretion of an antidiuretic substance and its relation to the hypothalamicohypophyseal system in cats. Am. J. Physiol., 1939, 127, 544.

28. Boylston, G. A., and Ivy, A. C., An antidiuretic substance present in the urine of dehydrated rats. Proc. Soc. Exper. Biol. and Med., 1938, 38, 644.

29. Ham, G. C., and Landis, E. M., A comparison of pituitrin with the antidiuretic substance found in human urine and placenta. J. Clin. Invest., 1942, 21, 455.

30. Heller, H., and Urban, F. F., The fate of antidiuretic principle of post-pituitary extracts. J. Physiol., 1935, 85, 502.

31. Patek, A. J., Jr., and Post, J., Treatment of cirrhosis of the liver by a nutritious diet and supplements rich in vitamin B complex. J. Clin. Invest., 1941, 20, 481. 